\title{
Ethical Implications of Economic Responsibilities
}

\author{
Ralf Lüfter \\ Faculty of Economics and Management, Free University of Bozen-Bolzano, Bolzano, Italy
}

\begin{abstract}
The focus of the present research is on the notion of economic responsibility as it was first introduced by Jean Maurice Clarke in the early 20th century and further expounded on by Milton Friedman half a century later. Thereby the aim is neither to present a historical and systematic description of validated positions nor to draw a comparison between them, but rather to elaborate on a sufficiently distinctive characterization of the ethical questions implied, though not explicitly presented, in the concepts of economic responsibility. The research is carried out against the backdrop of the premise of the precedence of reason and constitutive for the tradition of metaphysical thinking. It involves critical distinctions characteristic of Immanuel Kant’s ethics.
\end{abstract}

Keywords: ethics, economic responsibility, moral obligation, philosophical foundations of economics

\section{Introduction}

In the following, we focus on the notion of economic responsibility as it was first introduced by Jean Maurice Clarke (1916) in the early 20th century and further expounded on by Milton Friedman (1970) half a century later. Thereby, as the title of the article suggests, we aim neither to present a historical and systematic description of accepted positions nor to draw a comparison between them, but rather to elaborate on a sufficiently distinctive characterization of the ethical questions implied, though not explicitly presented, in the conceptualization of economic responsibility. In this regard, selected text passages from Jean Maurice Clark as well as Milton Friedman serve as examples, insofar as both authors are, to this day, points of reference in the relative field of study (Köhne, 2017). Neither of them addressed ethical questions explicitly, although their contributions concerning economic responsibility implicitly answer these same questions that eventually turn out to be constitutive of the groundwork of their concepts. This conjuncture is essential in as far as what emerges as constitutive of economic responsibility from the outset, and hence remains fundamental to its conceptualization and has been introduced unquestioningly.

The intended diagnosis provides no reflection on the reliability and correctness of given answers, it is neither interested in the amelioration of concepts in view of desirable effects nor in a critique of the basilar orientation concerning their worldview, but it remains confined to the reduction of the said answers to those fundamental questions that originally necessitated them. This is to say, its aim is to enrich the scholarly debate on economic responsibility by establishing an ethically inspired approach which reduces relative concepts to the necessary, not in terms of diminishing or condensing their form and content, but in terms of bringing them back to their fundamental structure of sense which, in the first place, informs what eventually turns out to be a scientific theory in its own right. Moreover, "to reduce to the necessary" means to restore the conditions which originally enabled

Ralf Lüfter, Ph.D., assistant professor of Moral Philosophy, Faculty of Economics and Management, Free University of Bozen-Bolzano, Bolzano, Italy. 
the conceptualization of economic responsibility as we understand it today. These very same conditions are those reasons on the basis of which the said concepts are established, asserting their plausibility. In other words, these very same conditions are the ground on which the claim of truth of the said concepts appears to be reasonable, and thanks to which they are understood and accepted as scientific theories on economic responsibility.

\section{The Precedence of Reason}

Accordingly, the intended diagnosis has to distinguish between, on the one hand, those reasons explicitly given by Jean Maurice Clark and Milton Friedman when addressing economic responsibility and, on the other hand, implicit reasons assumed unquestioningly that emerge just along with ethical questions, in as far as what these questions unearth in the first place appears to be questionable in itself, and therefore in need of an answer so as to become a sufficiently sustainable ground for the conceptualization of economic responsibility. ${ }^{1}$ In addition to this, the diagnosis has to comment on the correlation between the former and the latter kind of reason insofar as both are emblematic of the way in which economic responsibility is understood within the concepts of the mentioned authors. In order to see the problematic status of the said conjuncture, the central role assigned to the precedence of reason has to be recognized:

[Though] human understanding, wherever and whenever it is engaged, always and steadily looks out for the reason for which what encounters it, is, as it is. Understanding looks out for reason insofar as it requires, on its own terms, a statement of reason. Understanding requires the reduction-to-reason of propositions and assertations. [...] In all that encompasses and concerns them, the human representations seek reasons, often just the very proximate ones, occasionally even the more remote ones, finally the first and last reasons. (Heidegger, 2006, p. 13) ${ }^{2}$

As long as we rest upon this premise, the notion to which we entrust human understanding is the notion of an available reason for all that is attainable to be represented as being actual, being likely, as well as being necessary. In the tradition of metaphysical thinking ${ }^{3}$-in which ethical questions emerge on the grounds of the flagrant withdrawal of reason that informs the said precedence-this means that what is actual can be

\footnotetext{
${ }^{1}$ It can be shown that any concept of economic responsibility is based on assumptions that in their turn answer questions of ethical character. This is as much as to say that ethical questions raise issues that necessitate answers whenever and wherever economic responsibility is addressed and related concepts come up for discussion. The said issues are inherent to the notion of economic responsibility itself. In other words, concepts of economic responsibility are constituted in the form of, and can be read as answers to, these very questions.

““[Sodass] der menschliche Verstand selbst überall und stets, wo und wann er tätig ist, alsbald nach dem Grund Ausschau hält, aus dem das, was ihm begegnet, so ist, wie es ist. Der Verstand schaut nach dem Grund aus, insofern er selbst, der Verstand nämlich, die Angabe des Grundes verlangt. Der Verstand fordert Be-gründung für seine Aussagen und Behauptungen. [...] Das menschliche Vorstellen trachtet in all dem, wovon es umgeben ist und angegangen wird, nach Gründen, oft nur nach den nächstliegenden, bisweilen auch nach den weiter zurückliegenden, schließlich nach den ersten und letzten Gründen” (Heidegger, 2006, p. 13).

3 In the tradition of metaphysical thinking-generated through the question of being, while "being itself, [is] kept to its selfhood as a quære” (De Gennaro, 2013, p. XII) - the said premise is known as the principle of reason. In its shortened form it reads as follows: Nihilest sine ratione. It was introduced by Gottfried Wilhelm Leibniz who called it the principium magnum, grandeetnobilissimum (Heidegger, 2006, p. 196). In the academic year 1955/1956, Martin Heidegger gave a course of one-hour lectures at the University of Freiburg dedicated to the said principle. In the context of this course, he noted: "The short formulation mentioned earlier speaks in Latin. The formulation of the principle of reason was first mentioned and specifically discussed in the course of those meditations Leibniz carried out in the seventeenth century. In the West, however, philosophy has been reigning and transforming itself ever since the sixth century BC. Hence it took two thousand three hundred years until Western European thinking actually discovered and formulated the simple principle of reason. How odd that such an obvious principle, which always directs all human cognition and conduct without being stated, needed so many centuries to be expressly stated as principle in the formulation cited above. But it is even odder that we never wonder about the slowness with which the principle of reason came to light. One would like to call the long time it needed for this its 'incubation period': two thousand three hundred years for the posing of this simple [preposition]. Where and how did the principle of reason sleep for so long and presciently dream what is unthought in it?” (Heidegger, 1999, p. 4).
} 
represented truthfully on the condition that the reason for its actuality is understood as something available to human knowledge; what is likely ${ }^{4}$ can be represented truthfully on the condition that the reason for its likeliness is understood as something available to human knowledge; and what is necessary can be represented truthfully on the condition that the reason for its necessity is understood as something available to human knowledge. What appears to be knowable is understood on the basis of a contingent ${ }^{5}$ ground that can be adduced in such a way that it bears representations while delivering at the same time their defined scope. The presumed availability of a contingent ground ascertains the truth of what is understood, and therefore represented, as being actual, as being likely, and as being necessary. Accordingly, the precedence of reason is critical also for those contingent grounds that are supposed to ensure the truth of metaphysical thinking. They ensure what is, and its representations, as well as the correspondence between them. Philosophy, as well as all science up to now, has come about in the tradition of the precedence of reason by presupposing the availability of a reason in the form of a contingent ground that could be adduced wherever and whenever man aspires to understand something from scratch. What is aspired to in the first place is achieved through questioning. What is achieved through questioning is adduced as a sustainable ground for human representations. What is adduced

\footnotetext{
${ }^{4}$ An accurate elucidation of the meaning of "likely" and "likeliness" is given by Ivo De Gennaro in The Weirdness of Being (2013, 15 et seq.).

5 An introductory elucidation of the notion of contingency is provided by Gino Zaccaria in an interview entitled Tempo spazio arte (n.d.), published on the ScienzaNuova website: http://www.scienzanuova.org. A contingent being may be defined as an already constituted being which is supposed to persist independently from the existence of human beings. Thus, its persistence is assumed as an absolute given that can be taken for granted and consequently represented by the human being without any further necessity for questioning. A contingent being is furthermore an integral part of an already constituted, contingent reality within which human beings live and to which human beings are constantly related. All experiences of the said reality and of all beings contained in this reality, appear to be representable in terms of cause-effect relationships, i.e., in terms of lived impacts that are experienced by the human being, for example, the physico-chemical constitution of a tree. It is supposed to persist independently of the existence of the human being. Not only! It is also supposed to be the reason on the grounds of which the tree can be experienced in the first place. This is to say, the physico-chemical constitution of the tree is assumed as the subsistent reason thanks to which the tree can be represented by man as rooted in the earth, as soaring into the sky, as wide and uneven, as solid and deep green. All these appear to be mere properties of a tree. In fact, it seems that we look at mere properties of something that is a physico-chemical reality in the first place, whose physico-chemical reality appears to be the very reason on the grounds of which it has properties in the first place, and whose physico-chemical reality appears to be the reason on the grounds of which human beings are able to experience it in the first place. This is to say that the physico-chemical reality is assumed as the contingent reason on the grounds of which the tree is, after all, available for human representations. If we look more closely at what we have in sight here, then we become aware of the fact that a concrete and single tree is experienced as a contingent tree as the consequence of a preceding operation. This is to say that the concrete and single tree is considered in the light of an isolated trait common to all trees: its measurable and computable physico-chemical reality. This reality is assumed to be the substance of the tree as such in the whole. In other words, the tree as such in the whole is reduced to its measurable and computable physico-chemical reality which then becomes the abstract substance of each concrete tree. Undeniably, the physico-chemical composition of a concrete and single tree cannot be negated-neither can its measurability and computability-but it does not go without saying that the said composition is assumed as the substance of the tree as such in the whole. Consequently, the operation meant is in itself questionable. The contingent tree is not just given in an absolute way but as the result of the preceding operation illustrated, that can be called into question. In this regard, Gino Zaccaria’s The Light of Cézanne (2018) taught us a lesson. Referring to a letter which Paul Cézanne wrote to his friend Èmile Zola on April 9th, 1858, Gino Zaccaria comments: “[The artist] recalls the difference between the eye of the painter, for which the indoles of the pine is no mere indifferent, general concept, but rather the retracted origin of the uniqueness and singularity of this or of that tree, and that of the common vision is imposed by utility, according to which pine trees belong to the stock of so-called natural resources, and which shows a priori the character of being transformable into timber and firewood. The logger's axe cannot perceive the richness understood as flagrancy of the green colour in its contrast, on one hand, with the ardour of the sun and the celestial azure, and, on the other, with the darkness of the terrestrial abyss - a richness that is profusion and copiousness of truth. [...] We must therefore think of the painting Le grand pin as a way of letting go of the useable tree in order that the tree of flagrancy might be free, that it might clear [...]. The painting-which is not a 'reproduction' of a pine tree nor, much less, is a 'representation', but rather an entruing of its being -imposes a transformation of the common vision (the eye of the 'lived impact' and of contingency) in pictorial seeing: that seeing which refers and isdedicated solely to the truth. Indeed, Cézanne will write in his famous 'promise' to Émile Bernard that 'Je vousdois la verité en peinture et je vous la dirai’ [...]” (2018, p. 1).
} 
as a sustainable ground for human representations remains in itself questionable. What is in itself questionable requires answers. In other words, human understanding achieved through questioning requires the preceding questionability of a presupposed ground that on its side may be reduced-to-reason in the moment in which its contingency comes to light as such through related answers. Given answers ignore the said questionability in the moment in which the contingent ground is accepted as first or last reason. This is to say, the given answer preserves the said questionability only when a contingent ground is assumed in its need for reduction-to-reason, i.e., in which a contingent ground is assumed in its need to be reduced to the discontingent origin wherefrom it was adduced in the first place as a sustainable ground for human understanding. This is to say that the precedence of reason, as it was affirmed in the tradition of metaphysical thinking, gives rise to the notion of first and last reasons for which a further reduction could not be provided. In other words, it affirms the precedence of reason which is its own reason, whereas there are other reasons in the form of contingent grounds that require a further reduction in order to sustain human understanding.

Wherever and whenever such a contingent ground cannot be adduced through reduction-to-reason, assertations made on the basis of it are unfounded and therefore unjustified, i.e., propositions formulated on the basis of it are untrue while not corresponding to anything actual, to anything likely, and to anything necessary. Any related claim to truth, then, grasps at nothing and turns out to be unreasonable. Moreover, in the tradition of metaphysical thinking, the emergence of philosophical questions recalls the precedence of reason and therewith the notion of a first or last ground that eventually guarantees the truth of what is represented in the said assertations, i.e., in the said propositions. The preclusion of philosophical questions subjugates the precedence of reason inasmuch as the discontingent reason of any contingent ground remains unthought, like contingency itself. The contingent ground appears to be unquestionable. What appears instead of it is an unquestioned ground that is supposed to be without the need to be adduced or to be reduced-to-reason. What appears instead of it is a ground that is taken for granted as an absolute given. The circumstance that such a contingent ground was adduced remains unquestioned as well as the conditions of its adduction. In other words, the said ground is unreasonably assumed to be the sense-giving and sense-determining origin of what is available in terms of knowable. The said ground stands for a pre-established reason that was introduced "without having been explicitly originated by and through the freedom of man" and thus even prepared to be "calculated as an effect of other contingent circumstances" (De Gennaro, 2006, p. 84). Thereby, what is actual appears in the light of its mere effectiveness, what is likely appears in the light of its mere possibility, and what is necessary appears in the light of a linear causality. As a consequence, the knowable is prevalently seen in its calculable effectiveness, in its realizable possibility, and in its provable causality.

\section{The Necessity of Action}

According to the above-mentioned premise, only those representations for which a first or last reason can be adduced turn out to be founded. In other terms, only for those representations for which a reduction-to-reason is achievable and does the claim to truth seem to be justified. Headed by this premise, some representations may be considered to be rational and consequently to be determined by reason (Heidegger, 2006, p. 196). Here a second meaning of reason comes to light. "Reason" not only in the sense of a "ground that accounts for..." but also in the sense of "the way in which human beings perceive what is". Both meanings are relevant for the intended diagnosis: What is perceived in the first place as grounds for reasonable actions that are, moreover, considered to be responsible, is the acceptance of the presence of an obligation. According 
to the Oxford English Dictionary, "responsibility" refers to the human ability to fulfil obligations. "Reason" is understood as the human ability, on the one hand, to perceive the said obligation as a realizable end and, on the other hand, to adopt, in an appropriate way, the right means to fulfil it. Jean Maurice Clarke as well as Milton Friedman rely on this understanding of reasonable actions, from which their understanding of responsibility is derived. The attribution of their concepts of economic responsibility is bound to the notion of a linear relationship between an acting subject and the effects of their actions-and, at the same time, to the presence of different obligations within different contexts of actions within which responsibility is defined each time, depending on what is considered to be reasonable. The concepts of economic responsibility of both authors rely on the notion of obligations limited by respective contexts of action within which certain actions may be considered to be responsible, because of the fact that they are reasonable in terms of obligations that are fundamentally context-dependent.

In a free-enterprise, private-property system, a corporate executive is an employee of the owners of the business. He has direct responsibility to his employers. That responsibility is to conduct the business in accordance whit their desires, which generally will be to make as much money as possible while conforming to their basic rules of the society, both those embodied in law and those embodied in ethical custom [...] [T] he key point is that, in his capacity as a corporate executive, the manager is the agent of the individuals who own the corporation or the eleemosynary institution, and his primary responsibility is to them. (Friedman, 1970)

Of course, the corporate executive is also a person in his own right. As a person, he may have many other responsibilities that he recognizes or assumes voluntarily—to his family, his conscience, his feelings of charity, his church, his clubs, his city, his country. He may feel impelled by these responsibilities to devote part of his income to causes he regards as worthy, to refuse to work for particular corporations, even to leave his job, for example, to join his country's armed forces. If we wish, we may refer to some of these responsibilities as "social responsibilities". But in these respects he is acting as a principal, not an agent; he is spending his own money or time or energy, not the money of his employers or the time or energy he has contracted to devote to their purposes. If these are "social responsibilities", they are the social responsibilities of individuals, not business. (Friedman, 1970)

In the light of the precedence of reason, as was established within the tradition of metaphysical thinking, the confinement of an obligation to a limited context of actions that appears to be reasonable, becomes an evident problem insofar as actions may be considered responsible if context-dependent conditions are accepted, whereas the very same actions may be considered to be less responsible or even irresponsible, if some other conditions are considered to be more reasonable or the same conditions are considered to be unreasonable. Hence, we find ourselves in the situation of being unable to discern what in the first place requires a judgment and thus bears our considerations. We find ourselves unable to understand if an obligation persists for good reasons or not, i.e., whether it is a question of true obligation or a question of mere recommendation. Thus, we become disordered in midst of the beings as such and in the whole insofar as reduction-to-reason is suspended. But this is only the minor part of a wider problem that consist in the fact that even by confining the context of action, concepts of responsibility already answer implicit ethical question, i.e., questions that are principally related to the whole of sense-relations of human existence. This is to say that decisions, yes, may be confined to relative contexts, but only in as far as these contexts persist in the dimension of the said sense-relations, which therefore remains involved and is by no means suspended. Where ethical questions do not emerge, all efforts to orient ourselves turn out to be inert with regard to the questionable dimension. They depend on confined contexts, established within the said dimension on arbitrary suppositions, with the result that relative judgements are insufficiently critical and therefore ethically blank. 
The said problem was actually raised by Immanuel Kant in one of his earlier works when reflecting on the Fundamental Principles of Morality (Kant, 2005, pp. 96-97) and discussing the meaning of the term "ought" which, according to him, "expresses a necessity of action and is capable of two meanings" (Kant, 2005, pp. 96-97) while only one of the two has explicit ethical implications. Through the "ought” we are reached by a claim that in some way expects a response from us, waiting for whether we expose ourselves to it or not, waiting for whether we admit it and adopt it or not, waiting for our ability to fulfill it and waiting for whether we are responsible or not (Lüfter, 2015, p. 158). In the first meaning of the word, Immanuel Kant argues, no true obligation subsists while the necessity of the action refers exclusively to the choice of means he ought to adopt to an end in order to realize it. The said end is confined to a determined context of action so that the presumed obligation

merely specifies a prescription as the solution to a problem concerning the means I must employ if I am to attain a certain end. [...] In other words [it] would not be [an obligation] at all; [it] would simply [be a] recommendation to adopt a suitable procedure, if one wished to attain a given end. Now since no other necessity attaches to the employment of means than that which belongs to the end, all the actions which are prescribed by morality under the conditions of certain ends are contingent. They cannot be called obligations as long as they are not subordinated to an end necessary in itself. (Kant, 2005, pp. 96-97) ${ }^{6}$

Even though the notion of responsibility is not addressed in the cited text passage ${ }^{7}$, according to the above-introduced definition, we may state that under the conditions of a determined context of action, within which contingent ends suggest the adoption of certain means, no true responsibility subsists insofar as there is no true obligation that ought to be fulfilled. The notion of responsibility is then restricted to its merely responsive character (De Gennro \& Lüfter, 2018) ${ }^{8}$. All established ends are adduced from a predefined context

\footnotetext{
${ }^{6}$ In the original, the partially quoted passage reads as follows: "Man soll dieses oder jenes tun, und das andere lassen; dies ist die Formel, unter welcher eine jede Verbindlichkeit ausgesprochen wird. Nun drückt jedes Sollen eine Notwendigkeit der Handlung aus, und ist einer zwiefachen Bedeutung fähig. Ich soll nämlich entweder etwas tun (als Mittel), wenn ich etwas anderes (als einen Zweck) will, oder ich soll unmittelbar etwas anderes (als einen Zweck) tun, und würklich machen. Das erstere könnte man die Notwendigkeit der Mittel (necessitatem problematicam), das zweite die Notwendigkeit der Zwecke (necessitatem legalem) nennen. Die erste Art der Verbindlichkeit zeigt gar keine Verbindlichkeit an, sondern nur die Vorschrift als die Auflösung in einem Problem, welche Mittel diejenige sind, deren ich mich bedienen müsse, wie ich einen gewissen Zweck erreichen will. Wer einem anderen vorschreibt, welche Handlungen er ausüben oder unterlassen müsse, wenn er seine Glückseligkeit befördern wollte, der könnte wohl zwar vielleicht alle Lehren der Moral darunter bringen, aber sie sind alsdenn nicht mehr Verbindlichkeiten, sondern etwa so, wie es eine Verbindlichkeit wäre, zwei Kreuzbogen zu machen, wenn ich eine gerade Linie in zwei gleiche Teile zerfällen will, d.i. es sind gar nicht Verbindlichkeiten, sondern nur Anweisungen eines geschickten Verhaltens, wenn man einen Zweck erreichen will. Da nun der Gebrauch der Mittel keine andere Notwendigkeit hat, als diejenige, so dem Zwecke zukommt, so sind so lange alle Handlungen, die die Moral unter der Bedingung gewisser Zwecke vorschreibt, zufällig, und können keine Verbindlichkeiten heißen, so lange sie nicht einem an sich notwendigen Zwecke untergeordnet warden” (Kant, 2005, pp. 96-97).

${ }^{7}$ In the context of the quoted passage, Immanuel Kant refrains from defining more closely what the asserted necessity, and consequently the ultimate reason of a true responsibility, consists in; however, he concludes his reasoning by indicating the form of what could represent the said reason - namely: “ [...] the proposition: abstain from doing that which will hinder the realization of the greatest achievable accomplishment” (Kant, 2005, pp. 96-97). Thus, realizing the greatest accomplishment that is achievable through you, is the first formal ground of any true obligation to act, and therefore the reason of the ultimate responsibility of the human being. This is to say, according to Immanuel Kant's metaphysical position, human responsibility is, in the first place, bound to and determines by a principle of perfection, which, at any time, serves as the condition of possibility for acting in an ethically responsible way (Lüfter, 2015; De Gennaro \& Lüfter 2018).

${ }^{8} \mathrm{~A}$ responsible stance in which man merely responds to the claims of brute facts, may be called responsive. This is to say that a responsive decision is characterized by the fact that it does not involve a judgment concerning the context of action and therefore tends to turn into an automatized reaction. The context of action is then assumed as an absolute given and therefore not in need of any further reduction-to-reason. With regard to this circumstance, responsibility is connected to systematic imperatives-namely to operative conjunctions of brute facts which impose on man responsive actions, i.e., actions that obey the absolute claim of the sheer persistence of the system, which is in itself driven towards a continuous empowerment (De Gennaro \& Lüfter, 2018).
} 
of action within which the premise of the precedence of reason is not sufficiently settled as long as no end necessary in itself can be adduced. At this level, the emergence of ethical questions is not even achieved and, according to Immanuel Kant, only imperatives of second order are justified.

\section{The Emergence of Ethical Questions}

According to Immanuel Kant, an ethically relevant responsibility is inconceivable without presupposing that the human being is persistently addressed by the claim of an obligation and at the same time able to respond thereto and to fulfill the obligation to some extent ${ }^{9}$. His being-human is in itself and as such structured as a response. Being-human means being able to respond, and thus being responsible, while the said obligation serves as the condition of possibility for acting in an ethically responsible way, i.e., serves as the condition of possibility for being human. This is why Immanuel Kant argues that the question "What is the human being?" splices those three fundamental questions that combine all his interests of reason-the speculative ones as well as the practical ones: “What can I know? What ought I to do? What may I hope?” (2005, pp. 804-805). Within the tradition of metaphysical thinking, the said obligation is acknowledged as an inherent trait of the whole od sense-relations, in the midst of which the human being finds side for his dwelling. Therefore, and only therefore, ethical questions are, according to Immanuel Kant, supposed to be concerned with the said obligation, unearthing it as the ultimate reason for any true responsibility, i.e., unearthing it as the condition of possibility for acting in an ethically responsible way.

Ethical questions are questions related to ethics. Therefore, questions related to that form of knowledge

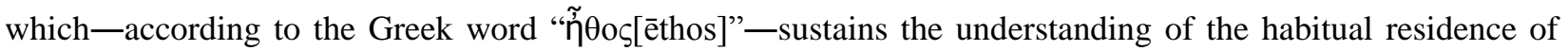
men. In other words, "ก̃ $\theta 0 \varsigma$ [êthos]" indicates the abode of men in the sense of the original dimension which allows for and welcomes human dwelling on earth under the sky in the first place (Liddell\& Scott, 1996, p.

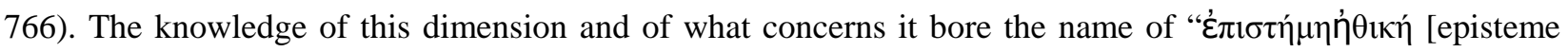
ethike]" (Heidegger, 1994, p. 199). The shortened term "ethics” derives from this name, "Ethos means dwelling, abode. We say: the dwelling of the human being, his abode in the midst of beings in the whole” (Heidegger, 1994, p. 215).

This insight, permitted by the Greek language, is to the present day the core of what we understand as ethics, in its classical as well as in its modern form, and in the form of applied moral science. The theory of virtue and the theory of value are, for example, expressions of the said understanding (Heidegger, 1994, p. 200). This understanding provides the frame within which the notion of responsibility became a, if not the key concept of ethics (De Gennaro \& Lüfter, 2018, p. 145). Accordingly, ethical questions are supposed to unearth the said original dimension - the whole of sense-relations-which allows for and welcomes human dwelling, human abode on the earth under the sky in the first place. Without the possibility, at this point, of further deepening our understanding of this dimension, we recall the circumstance that within the tradition of metaphysical thinking the notion of responsibility emerges in the light of another notion-the notion of an obligation that is conceived as being itself an inherent trait of the said original dimension, in the midst of which

\footnotetext{
${ }^{9}$ Roughly speaking, within the tradition of metaphysical thinking-for which Immanuel Kant's position is paradigmatic-the attribution of responsibility is based on a reason for discrimination in the form of a principle of perfection that serves as an ultimate criterion of truth. Only thanks to such a principle does the attribution of responsibility make sense, insofar as the human ability to respond is bound to such a principle and determined by it. According to Immanuel Kant, such an ultimate reason is the condition of possibility of acting in an ethically responsible way. The form of the said principle-that within the tradition of metaphysical thinking serves as reason for discrimination, i.e., as ultimate criterion of truth-is the form of perfection.
} 
the human being finds side for his/her dwelling. Both responsibility and obligation are ethically relevant only as far as the said whole of sense-relations is involved as ultimate reason for man to be man.

Considering the increasing interest in concepts of responsibility and their presence in political and scientific discourse, it seems quite surprising that, according to a validated historical reconstruction, only after the mid-19th century, did the term "responsibility" gain some currency in everyday and academic language. And it was not until the 20th century that the concept of responsibility-understood, prevalently, in terms of social responsibility_became a reference point for ethics as well as for moral science (Beyertz \& Beck, 2017). In line with this, the concept of economic responsibility was first introduced in 1916 with intent to overcome an "anachronism" (Clarke, 1916, p. 209) that consisted in the opinion, that economic responsibility could be conceived as mere "responsibility of the individual for his own economic destiny: his responsibility for paying his debts and keeping out of the poor-house” (Clarke, 1916, p. 209). Jean Maurice Clarke (1916) stated that "the ideas of obligation which embody the actual relations of man to man [...], and answer the needs of the twentieth century, are radically different from the ideas which dominated" (p. 209) the past centuries. "We have inherited an economics of irresponsibility" (p. 209), he wrote, unable to cope with present problems which have to be considered in the light of "new ideas of cause and effect", which require "new ideas of responsibility" (p. 213). According to this historical reconstruction, the rise of concepts of responsibility is the direct consequence of a profound transformation taking place in different spheres of human practice-in politics as well as in science, in technics as well as in economics; a transformation that eventually resulted in what today is referred to as the process of globalization. Accordingly, Jean Maurice Clarke states:

We need all the sense of responsibility we can arouse, of all kinds, organized and directed in the most intelligent and efficient channels to make even moderate satisfactory headway with the increasingly complex problems that are piling up ahead of us. (Clarke, 1916, p. 217)

And he continued: "We are coming to see that our everyday business dealings have more far-reaching effects than we have ever realized, and that the system of free contract is by itself quite inadequate to bring home the responsibility for these effects.” (Clarke, 1916,p. 218) The manifold challenges implied by the said transformation process are considered to have led to a discussion of the notion of responsibility prevalently in the light of the problem of attribution, which recently appeared to be the core question referring to concepts of responsibility (Jonas, $1979^{10}$; Lenk, 2017; Loth, 2017).

This has far-reaching implications for the understanding of responsibility, implications that are also defining for the conceptualisation of economic responsibility in the 20th century. The problem of attribution emerges on grounds of the condition that responsibility is tied to a linear relationship between an acting subject and the effects of their action (De Gennaro \& Lüfter, 2018). The notion of responsibility is then defined by this linear relationship and thereby confined to a restricted context of action within which pressing problems require

\footnotetext{
${ }^{10}$ Hans Jonas argues that a new kind of ethical position is needed as a response to an entirely new and unpredicted situation. That new position, which is meant to surrogate the insufficiency of ethical reasoning within the tradition of metaphysical thinking, requires a new imperative that Hans Jonas himself calls the ecological imperative. "Was der Mensch heute tun kann und dann, in der unwiderstehlichen Ausübung dieses Könnens, weiterhin zu tun gezwungen ist, das hat nicht seinesgleichen in vergangener Erfahrung. Auf sie war alle bisherige Weisheit über rechtes Verhalten zugeschnitten. [...] Das Neuland kollektiver Praxis, das wir mit der Hochtechnologie betreten haben, ist für die ethische Theorie noch ein Niemandsland” (Jonas, 1979, p. 7)—“What present-day man can do, and therefore, in the irresistible exercise of his power, is compelled to keep on doing, has no equivalent in past experiences. However, our entire wisdom concerning the proper way to be was tailored to those experiences. [...] The virgin land of collective practice, that we have begun to walk on with the advent of high technology, is still a no man's land for ethical theory” (Trad. by Ivo De Gennaro).
} 
effective responses. As long as these responses and their effects are justified by the pressing nature of eminent problems, the above-introduced premise of the precedence of reason seems to be suspended where it is not. In fact, the emergence of the said problems as well as their urgency subsist on grounds of a pre-defined contexts of action, while the assumption of this pre-defined context of action itself would require a reduction-to-reason in as far as it does not go without saying. Consequently, the urgency of context-related problems does not provide evidence of the presence of true obligations. The notion of responsibility cannot be reduced to its responsive character however efficient it may seem, neither can obligations be replaced by urgency of context-dependent problems. The said urgency subsists only on grounds of a restricted context of action; it does not subsist by itself, and thus, according to Immanuel Kant, it presents no true obligation in that it isnot necessary in itself. Urgency refers to problems which emerge in a pre-defined context of action and require responsive actions on condition that the said problems interfere with the persistence of the said context, but not unconditionally. According to Immanuel Kant, we can state that they inform obligations on a hypothetical level, not on a categorical one, i.e., obligations of a second order, i.e., not true obligations. This is to say that the original dimension which allows for and welcomes human dwelling in the first place is replaced, without giving any further reason, by a pre-defined context of action that is assumed randomly. ${ }^{11}$

The discussion of the notion of responsibility prevalently in the light of the problem of attribution, meets today's understanding of the expression "to be responsible", which according to the above-mentioned definition means "to be able to fulfil an obligation". The attribution of responsibility on the basis of the notion of a linear relationship between an acting subject—be it an organization, a collective, or an individual—and the effects of their action is, on the one hand, determined by the ability to achieve an effect and, on the other hand, by the subsistence of a true obligation as an ultimate reason. What we see at this point, is that the notion of responsibility, based on the notion of a linear relationship between the acting subject and the effects of their action is in itself not sufficient to define the notion of responsibility as such, so that the scope of this linear relationship has to include the notion of an end in the form of an effect that ought to be fulfilled by obligation. In the sense assumed here, "to be responsible" means "to be capable of responding to an obligation" in the first place. In other words, the said obligation is supposed to appear to be an end that ought to be realized through action as an effect of it. Consequently, it is this end that offers the ultimate reason for being responsible as far as it is open to being realized as a desirable effect. As this very reason it offers, secondly, an action-orientation insofar as it is not only open to being realized but ought to be realized. Consequently, as this reason, it offers, thirdly, a decision criterion on the basis of which an action can be considered responsible or irresponsible, insofar as exclusively thanks to it we can state that an obligation was fulfilled, or remained unfulfilled, or was fulfilled to some extent.

In the tradition of metaphysical thinking, there are forms of knowledge engaged in the determination of the ultimate ends of human action, e.g., ethics and theology; and there are forms of knowledge engaged in the allocation of those means through which the said ends could be eventually realized, e.g., economics and technics. It was in the course of the above-mentioned transformation that especially economics became, unnoticed, a form of knowledge that now determines autonomously the ends of human action that ought to be realized in the first place (De Gennaro, 2006, p. 78). In relation to this, ethics becomes a subordinate form of

11 This is true for the tradition of metaphysical thinking, whereas in the very moment in which thinking itself becomes the overcoming of this tradition the attempted diagnosis has to be pursued. 
knowledge with corrective functions. Concepts of responsibility then become defined means to economically pre-defined ends, i.e., means of control for corrective exercises within an already established context of actions. This is to say that the notion of responsibility is confined to a pre-defined context of action, while losing sight of the implications related to the beings as such and in the whole, i.e., while losing sight of the ethical implications.

\section{The Scope of Economic Responsibility}

In this regard, the generally referred-to Friedman-Doctrine may serve as an example. In an article published in 1970 by the New York Times Magazine, entitled "The Social Responsibility of Business is to increase its Profits”, the same Milton Friedman sustains, that it does not go without saying that we speak about something, like business responsibilities, management responsibilities, and economic responsibilities, claiming that there are major implications beyond the scope of business, beyond the scope of management, and beyond the scope of economics that can aspire to some ultimate status. His article is not least on the scope of responsibility, while he argues that in the case of business as well as in the case of management and in the case of economics, responsibility is confined to a restricted context of action pre-defined by what is assumed to be business reason, management reason, or, generally speaking, economic reason.

When I hear businessmen speak eloquently about the "social responsibilities in a free-enterprise system”, I am reminded of the wonderful line about the Frenchman who discovered at the age of 70 that he has been speaking prose all his life. The businessmen believe that they are defending free enterprise when they declaim that business is not concerned "merely" with profit but also with promoting desirable "social” ends. [...] In fact they are [...] preaching pure and unadulterated socialism. Businessmen who talk this way are unwitting puppets of the intellectual forces that have been undermining the basis of free society these past decades. (Friedman, 1970)

By assuming unquestioningly that the notion of responsibility is defined by the notion of a linear relationship between the acting subject and the effects of their action and thereby confined to a restricted context of action-the economic context-Milton Friedman adopts the notion of profit as an ultimate end which ought to be pursued and eventually realized. This is to say that within the economic context profit turns out to be a good reason to do something and to abstain from doing the other. It offers an action-orientation insofar as it is not only open to being realized but ought to be realized in the first place, as long as a pre-defined economic context is accepted. Furthermore it offers a decision criterion on the grounds of which actions can be considered to be economically responsible or economically irresponsible.

There is one and only one social responsibility of business- to use its resources and engage in activities designed to increase its profits so long as it stays within the rules of the game, which is to say engages in open and free competition without deception and fraud. (Friedman, 1970)

In a free-enterprise, private property system, a corporate executive is an employee of the owners of the business. He has direct responsibility to his employers. That responsibility is to conduct the business in accordance with their desires, which generally will be to make as much money as possible while confirming to their basic rules of the society, both those embodied in law and those embodied in ethical custom.[...] Of course, the corporate executive is also a person in his own right. As a person, he may have many other responsibilities that he recognizes or assumes voluntarily-to his family, his conscience, his feelings of charity, his church, his clubs, his city, his country. [...] If we wish, we may refer to some of these responsibilities as "social responsibilities". But in these respects he is acting as a principle, not an agent; he is spending his own money or time or energy, not the money of the employers or the time or energy he has contracted to devote to their purposes. If these are "social responsibilities", they are the social responsibilities of individuals, not business. (Friedman, 1970) 
Milton Friedman is not denying that there may be some other contexts of action than the economic one, where it seems to be reasonable that some other ends ought to be realized, so that what is considered to be responsible changes accordingly. Nonetheless, following his argumentation, the constellation between the notion of an end that ought to be realized through action, the notion of an action in terms of a linear relationship between acting subject and the effects of their actions, and the notion of a pre-defined action context does not change. And we see that, according to Milton Friedman, different contexts always imply different ends. Different ends inform different contexts. We can therefore imagine that different contexts may exist simultaneously without interference, as well as we can imagine the collision or even the superposition of different contexts. It does not change, in principle, the assumed constellation. This is to say that the problem raised above persists, namely, the problem that the premise of the precedence of reason is not sufficiently settled as long as no end necessary in itself can be adduced. At the same time, the supposed constellation that bears the concept of responsibility introduced follows this premise as long as it claims to be reasonable and not merely arbitrary. All context-dependent ends remain unreasonable, i.e., constantly in need of a reduction-to-reason, just as all related obligations and responsibilities appear to be questionable. The problem of the insufficiency raised is a constitutive part of the concepts of responsibility presented here, and therefore one of its implicit traits that emerges against the backdrop of the tradition of metaphysical thinking, i.e., against the backdrop of a classical position of ethics, like Immanuel Kant's, and its fundamental questions. These questions may be said to be ethical insofar as they remain related to the whole of sense-relations of human existence, i.e., to the questionable dimension which allows for and welcomes human dwelling in the first place.

The above-mentioned constellation persists regardless of whether we assume that by satisfying the Friedman- Doctrine, businessmen contribute to the wealth of society in general, and therefore act in its best interests, or we assume just the opposite, that by satisfying the Friedman-Doctrine, businessmen contribute to the decline of wealth of society in general, and therefore act against its best interests. Inevitably, the said questions of ethical character emerge, not least, in the light of the constellation concerned. As long as we are not able to reduce-to-reason the original dimension wherefrom the context of action as well as its related end was adduced, concepts of economic responsibility remain ungrounded. Ethical questions inform the conceptualization of economic responsibility, at least as long as the conceptualization is determined by the assumption that "to be responsible" means "to be capable of fulfilling an obligation", presupposing that "to fulfill” means "to act in the sense of producing effects", on the basis of a linear relationship between the acting subject and the effects of their action, within a pre-defined context of action.

\section{The Private and the Public Use of Reason}

In conclusion, considering the emergence of ethical questions without pretermitting the precedence of the reason, a further distinction, introduced by Immanuel Kant in his writing What is Enlightenment?, will help us to discuss the scope of concepts of economic responsibility, namely, the distinction drawn between the private use of reason and the public use of reason.

According to the Oxford English Dictionary, one of the main meanings of the word "reason" is "ability to adopt an action to a certain end". This is to say that actions that appear to be reasonably responsible are characterized by "the human ability to fulfill an obligation" (responsibility) by means of "adopting an action to an end" (reasonably on good grounds). This is to say that the distinction drawn between the private use of reason and the public use of reason will be related to the human ability to realize, by means of action, an end. 
To be more precise, the said distinction will be related to the original human ability to be responsible in a way that is supposed to be reasonable.

Laziness and cowardice are the reasons why such a large part of mankind gladly remain minors all their lives, long after nature has freed them from external guidance. They are the reasons why it is so easy for others to set themselves up as guardians. It is so comfortable to be a minor. If I have a book that thinks for me, a pastor who acts as my conscience, a physician who prescribes my diet, and so on-then I have no need to exert myself. I have no need to think, if only I can pay. (Kant, 2005, p. 482) ${ }^{12}$

When Immanuel Kant says "to exert myself”, he means "to be what I am” in the sense of "to be what I already am”, i.e., "to become what I already was”.

Enlightenment requires nothing but freedom—and the most innocent of all that may be called "freedom": freedom to make public use of one's reason in all matters. Now I hear the cry from all sides: "Do not reason!” The officer says: "Do not reason—drill!” The tax collector: "Do not reason—pay!” The pastor: "Do not reason—believe!” Only one ruler in the world says: "Reason as much as you please, but obey!” [...] The public use of one's reason must be free at all times, and this alone can bring enlightenment to mankind. (Kant, 2005, p. 484) ${ }^{13}$

The ruler meant, we should like to assume, is truth. Here and now, we certainly cannot afford a thorough study of the nature of truth, neither in the sense in which the metaphysical tradition developed it, nor in the precise sense in which Immanuel Kant understood it. But we can introduce it as the "stadtholder" for what we assume as the presumed end of the public use of reason. This is to say that truth implies something such as a human togetherness, something such as a human coalescence insofar as it indicates that dimension on which we, as human beings, ultimately rely (Borghi, 2011). Consequently, according to Immanuel Kant, truth turns out to be the dimension of reliance that allows for human togetherness, human coalescence. We may add that in this regard $\tilde{n} \theta \mathrm{o} \varsigma$ is that trait proper to the dimension of truth that offers the site for dwelling for human togetherness, for human coalescence.

Something turns out to be true in as much as human beings rely on it in the first place, when relating to what is, when relating to other human beings, when relating to themselves.

The trait of reliance is confirmed by the way in which the English language itself understands the word "truth" (that stems from an Old-English word that means "faithful, trust, trustworthy”). For instance, what we call "a true argument” is not primarily an argument which is factually or rationally correct, but an argument we can rely on. Similarly, a "true hammer" is not just a hammer which is non-imaginary and "real” but primarily a hammer we can trustfully rely on when hammering a nail to the wall [...] A "true man” is someone on whose humanity we can rely. (Borghi, 2011, $16 \mathrm{f}$.)

Any form of human togetherness, any form of human coalescence remains from the ground up tied to the notion of truth. Therefore, the end of the public use of reason is, according to Immanuel Kant, the furtherance

\footnotetext{
12 "Faulheit und Feigheit sind die Ursachen, warum ein so großer Teil der Menschen, nachdem sie die Natur längst von fremder Leitung freigesprochen, dennoch gern zeitlebens unmündig bleiben; und warum es anderen so leicht wird, sich zu deren Vormündern aufzuwerfen. Es ist so bequem unmündig zu sein. Habe ich ein Buch, das für mich Verstand hat, einen Seelsorger der für mich Gewissen hat, einen Arzt, der für mich die Diät beurteilt usw., so brauche ich mich ja nicht selbst zu bemühen. Ich habe nicht nötig zu denken, wenn ich nur bezahlen kann” (Kant, 2005, p. 482).

13 “Zu dieser Aufklärung aber wird nichts erfordert als Freiheit; und zwar die unschädlichste unter allem, was nur Freiheit heißen mag, nämlich die: von seiner Vernunft in allen Stücken öffentlichen Gebrauch zu machen. Nun höre ich aber von allen Seiten rufen: Räsoniert nicht! Der Offizier sagt: Räsoniert nicht, sondern exerziert! Der Finanzrat: Räsoniert nicht, sondern bezahlt! Der Geistliche: Räsoniert nicht, sondern glaubt! Nur ein einzige Herr in der Welt sagt: Räsoniert, soviel ihr wollt, aber gehorcht! [...] Der öffentliche Gebrauch seiner Vernunft muß jederzeit frei sein, und der allein kann Aufklärung unter Menschen zustande bringen” (Kant, 2005, p. 484).
} 
and the maintenance and eventually the realization of truth as reliance. The claim for the realization of the said end is a true obligation, which can be fulfilled exclusively by men who can afford freedom, i.e., by men who have the courage to make public use of their own reason in all matters and who, therefore, are able to act in a responsible way.

By "public use of one's reason” I mean that use which a man, as scholar, makes of it before the reading public. I call "private use" that use which a man makes of his reason in a civic post that has been entrusted to him. In some affairs affecting the interest of the community a certain mechanism is necessary in which some members of the community remain passive. This creates an artificial unanimity which will serve the fulfillment of public objectives, or at least keep these objectives from being destroyed. Here reasoning is not permitted: one must obey. [...]

Thus it would be very unfortunate if an officer on duty and under orders from his superiors should want to criticize the appropriateness or utility of his orders. He must obey. But as a scholar he could not rightfully be prevented from taking notice of the mistakes in the military service and from submitting his views to his public for its judgment. [...]

[A]s the scholar who speaks to his own public (the world) through his writings, [...] enjoy unlimited freedom to use its own reason and to speak for himself. (Kant, 2005,pp. 485-488) ${ }^{14}$

If the concept of economic responsibility is supposed to claim that human beings have an obligation to act for good reasons, then this, in Immanuel Kant's view, will take place only under the circumstance that human beings make public use of their reason - to wit: of their ability to fulfill an obligation, adopting an action to the said end, i.e., the obligation to enlighten all aspects of the dimension on which they, as human beings, rely in the first place. As long as human beings make only private use of their reason, they do not act responsibly but only for reasons of mere context-dependent ends which cannot be considered to maintain and further and eventually realize reliance as such.

In order to add one more degree of precision, we may say that the end meant has to be understood according to the German word "öffentlich". In fact, the English word "public” is not fit for translating "öffentlich" in the sense in which Immanuel Kant understands it. The meaning of "öffentlich" goes in the direction of what is "open" in the sense of "suspended" in such a way that its very suspension constitutes that which has to be pondered over in the first place, that which has to be thought about in the first place, and that which therefore remains the constant source of any genuine human reasoning. Now, it seems quite clear why the private use of reason is irresponsible. It is from scratch subjected to the pre-supposed end of a pre-defined context which is never "open", never "suspended". What emerges is not reliable in as much as the assumed context and the assumed end are not seen in their questionability and adopted as a given. Then, no reduction-to-reason can take place. The human togetherness is thought of as a coalescence where human beings are bound by the circumstance that they share a responsibility towards truth itself. Everyone is expected to

\footnotetext{
14 "Ich verstehe aber unter dem öffentlichen Gebrauch seiner Vernunft denjenigen, den jemand als Gelehrter vor dem ganzen Publikum der Leserwelt macht. Den Privatgebrauch nenne ich denjenigen, den er in einem gewissen ihm anvertrauten bürgerlichen Posten oder Amte von seiner Vernunft machen darf. Nun ist zu manchen Geschäften, die in das Interesse des gemeinen Wesens laufen, ein gewisser Mechanismus notwendig, vermittelst dessen einige Glieder des gemeinsamen Wesens sich bloß passiv verhalten müssen, um durch eine künstliche Einhelligkeit von der Regierung zu öffentlichen Zwecken gerichtet oder wenigstens von der Zerstörung dieser Zwecke abgehalten zu werden. Hier ist es nun freilich nicht erlaubt zu räsonnieren, sondern man muss gehorchen [...] So würde es sehr verderblich sein, wenn ein Offizier, dem von seinen Oberen etwas anbefohlen wird, im Dienste über die Zweckmäßigkeit oder Nützlichkeit dieses Befehls laut vernünfteln wollte; er muss gehorchen. Es kann ihm aber billigermaßen nicht verwehrt werden, als Gelehrter über die Fehler im Kriegsdienst Anmerkungen zu machen und diesem seinem Publikum zur Beurteilung vorzulegen. [...] [A]ls Gelehrter, der durch die Schriften zum eigentlichen Publikum redet, nämlich der Welt spricht, [...] genießt einer uneingeschränkten Freiheit, sich seiner eigenen Vernunft zu bedienen und in seiner eigenen Person zu sprechen” (Kant, 2005, pp. 485-488).
} 
contribute and one does so by simply having the courage to make public use of one's capability to adopt one's thinking; acting to an end has to be, every time, anew, sensed, mentioned, and said.

\section{Conclusion}

According to the presented line of reasoning it can be argued that the notion of economic responsibility implies assumptions that in their turn answer questions of ethical character. Even where the reference to these questions is not explicit they constitute the basis of our understanding of the said notion in such a way that they inform its conceptualization from the scratch. This is as much as to say that the very same questions raise issues that necessitate answers whenever and wherever economic responsibility is addressed and related concepts come up for discussion. The said issues are inherent to the notion of responsibility itself. They cannot be avoided by the introduction of limited contexts of action or by posing obligations that appear to be fundamentally context-dependent. Consequently the notion of economic responsibility cannot be defined on the basis of context-dependent conditions but require a reduction-to-reason which considers the whole of sense-relations of human existence. Decision-making processes may be confined to relative contexts, but only in as far as these contexts persist in the dimension of the said sense-relations, which therefore remains involved and is by no means suspended. The original name of the said dimension - which allows for and welcomes human dwelling on earth under the sky in the first place - is $\tilde{n} \theta$ os $[\bar{e}$ thos]. Questions related to this dimension i.e. ethical questions - are supposed to unearth its ineluctable relevance for the notion of economic responsibility.

\section{References}

Beyertz, K., \& Beck, B. (2017).Der Begriff der Verantwortung in der Moderne: 19.-20. Jahrhundert [The Concept of Responsibility in the Modern Age. $19^{\text {th }}-20^{\text {th }}$ Century].In L. Heidbrink, C. Langbehn, and J. Loh (Eds.), Handbuch Verantwortung [Handbook of responsibility], pp. 133-147). Berlin: Springer.

Borghi, M. (2011). Copyright and truth. Theoretical Inquiries in Law, 12(1), 1-29.

Clarke, J. M. (1916). The changing basis of economic responsibility. Journal of Political Economy, 24(3), 209-229.

De Gennaro, I. (2006). Building leadership on the invaluable. Towards the groundworks for a phenomenological approach to the philosophy of management. AncillaIuris, 78, 78-87.

De Gennaro, I. (2013). The weirdness of being: Heidegger's unheard answer to the Seinsfrage. Durham: Acumen.

De Gennaro, I., \& Lüfter, R. (2018). "La perfezione tra passato e futuro. Per una diagnosi etica della responsabilità sociale” [The perfection between past and future. Towards an ethical diagnosis of social responsibility]. In F. Miano (Ed.), Etica $e$ responsabilità [Ethics and responsibiliti] (pp. 145-156). Napoli-Salerno: Ortothes.

De Gennaro, I., \& Zaccaria, G. (2011). The dictatorship of value: Teaching and research in the Planetary University. Milano: McGraw-Hill.

Friedman, M. (1970). The social responsibility of business is to increase its profits. The New York Times Magazine. Retrieved from http://umich.edu/ thecore/doc/Friedman.pdf

Heidegger, M. (1994). Heraklit [Heraclitus], HGA Bd. 55. Frankfurt am Main: Klostermann.

Heidegger, M. (1999).The principle of reason.(R. Lilly, Trans.).Bloomington and Indianapolis: Indiana University Press.

Heidegger, M. (2006). Der Satzvom Grund [The principle of reason]. Stuttgart: Klett-Cotta.

Jonas, H. (1979). Das Prinzip Verantwortung: Versuch einer Ethik für die technologische Zivilisation[The Imperative of responsibility. In search of an Ethics for the Technological Age]. Frankfurt am Main: Suhrkamp.

Kant, I. (2005). Werke in sechs Bänden [The works in six volumes].Darmstadt: Wissenschaftliche Buchgesellschaft.

Köhne, R. (2017). Ökonomische Verantwortung [Economic responsibility]. In L. Heidbrink, C. Langbehn, and J. Loh (Ed.), Handbuch Verantwortung[Handbook of responsibility] (pp. 607-623). Berlin: Springer. 
Lenk, H. (2017). Verantwortlichkeit und Verantwortungstypen: Arten und Polaritäten [Resposnability and types of responsibility. Forms and Polarities].In L. Heidbrink, C. Langbehn, and J. Loh(Ed.), Handbuch Verantwortung [Handbook of responsibility](pp. 57-84). Berlin: Springer.

Liddell, H. G., \& Scott, R. (1996). Greek-English lexicon. Oxford: Calderon Press.

Loth, J. (2017). Strukturen und Relata der Verantwortung [Structures and references of responsibility]. In L. Heidbrink, C. Langbehn, and J. Loh (Ed.), Handbuch Verantwortung [Handbook of responsibility] (pp. 35-56).Berlin: Springer.

Lüfter, R. (2015). The future of sustainability: Philosophy Study (5/2015). New York: David Publishing.

Zaccaria, G. (2018). The light of Cézanne: Errancy into the sun. Yearbook of Philosophy, Poetry, and Art, (12), 1-7. Retrieved February 13, 2019, from http://www.eudia.org

Zaccaria, G. (n.d.). Tempo spazio arte 1 [Time space art 1]. Scienza Nuova Website. Retrieved February 13, 2019, from http://www.scienzanuova.org 